\title{
Undocumented Students' Experiences With Microaggressions During Their College Choice Process
}

\author{
H. KENNY NIENHUSSER \\ University of Hartford \\ BLANCA E. VEGA \\ Teachers College, Columbia University \\ MARIELLA CRISTINA SAAVEDRA CARQUIN \\ Kingsborough Community College
}

\begin{abstract}
Background/Context: Although millions of undocumented students are enrolled in and guaranteed free public K-12 education, their postsecondary education opportunities are stifled. Some of the barriers encountered by undocumented students include discriminatory public policies, limited availability of information and insensitive college choice processes, and fear of immigration status disclosure.
\end{abstract}

Research Question: The research question that guided this study was: How, if at all, do undocumented students experience microaggressions during their college choice process?

Research Participants: A total of 15 undocumented immigrants were interviewed and consisted of 10 females and 5 males. Twelve identified as Latina/o and 3 as Asian. Two participants never enrolled in postsecondary education. Of the 13 participants who enrolled in postsecondary education, 12 enrolled in a New York State public institution (one attended a public out-of-state university). Nine of the interviewees initially attended a four-year college, and 4 originally enrolled in a two-year institution.

Research Design: This qualitative phenomenological study included in-depth semistructured interviews with 15 undocumented students who attended New York City high schools.

Findings: The findings identify nine themes in the area of microaggressions that research participants faced during their college choice process: discriminatory financial aid policies, restricted college choice information, constrained life opportunities, denial of college opportunities, insensitive behaviors, insensitive college choice processes, narrowed college expectations, fear of coming out, and undocumented immigrant blindness. Every respondent who participated in our study encountered multiple episodes of these microaggressions in their college choice process. We found that the participants faced cumulative and negative messages,

Teachers College Record Volume 118, 010209, February 2016, 33 pages

Copyright (C) by Teachers College, Columbia University

0161-4681 
behaviors, and environmental cues that pervaded their college choice process. Also, seemingly well-intentioned institutional agents often delivered many of the microaggressions encountered by students.

Conclusions: The authors conclude the need to eliminate discriminatory postsecondary education policies that shape the educational journeys of undocumented students. Also, they challenge education institutional agents to create environments and processes that better address undocumented students' college access needs.

Being undocumented [is] like living in [an] invisible prison . . . you're trapped there behind these invisible bars, and you're stuck there ... . Limited access and the lack of knowledge, especially as a young youth back then, really limited me and my choices in life and ... colleges I wanted to go to.

- Interviewee who attended a four-year out-of-state postsecondary institution

Over 2 million undocumented students are enrolled in the U.S. K-12 education system (Congressional Budget Office, 2007). Although free public K-12 education is guaranteed to undocumented students, their postsecondary education opportunities are obstructed. In fact, a mere $25 \%$ of undocumented immigrants who are between the ages of 25 and 64 have enrolled in college, compared with $53 \%$ of documented immigrants and $62 \%$ of individuals of the same age group born in the United States (Passel \& Cohn, 2009). Despite the benefits afforded by Deferred Action for Childhood Arrivals (DACA), ${ }^{1}$ DACA recipients and undocumented students are not guaranteed any federal financial aid (Olivas, 2012), and currently only five states provide undocumented students with eligibility for state postsecondary education benefits (Institute for Higher Education Law and Governance [IHELG], 2014; Nienhusser, 2015). These realities indicate that a closer examination of undocumented immigrants' college access is crucial, especially around how this population experiences their college choice process.

Undocumented immigrants are individuals who are not U.S. citizens, do not hold current permanent resident visas, and have not been granted admission under rules for longer term residence or work permits (Passel \& Cohn, 2010). We use the term undocumented students to refer to the period when respondents were enrolled in $\mathrm{K}-12$ or postsecondary education, and the phrase undocumented immigrants to reflect their posteducation lives.

In recent years, the debate over undocumented students' eligibility for postsecondary education benefits has gained the attention of the public 
and policy makers (Dougherty, Nienhusser, \& Vega, 2010). Some proponents of undocumented immigrants receiving higher education benefits present arguments such as: (a) undocumented students had no part in their decision to immigrate to the United States and should not be punished for their parents' actions; (b) undocumented students who qualify for postsecondary education benefits have been educated in U.S. schools, and denying them access to higher education may facilitate an unwanted underclass; (c) countries have a moral responsibility to provide full educational access to their long-term residents regardless of immigration status; and (d) individual states have the right to determine postsecondary education benefits afforded to their residents (Perry, 2004). On the other hand, the Federation for American Immigration Reform (FAIR), a conservative interest group, for example, presents three arguments in their opposition to undocumented immigrants receiving postsecondary education benefits: (a) the responsibility of educating undocumented immigrants should fall on their countries of birth; (b) postsecondary education benefits for undocumented immigrants limit opportunities for "legal" residents and citizens; and (c) higher education policies that benefit undocumented students will encourage more undocumented immigrants into the country (Federation for American Immigration Reform [FAIR], 2005; Perry, 2004). As this debate continues, countless undocumented students have been caught up in this dispute, and as a result, their higher education opportunities have been hindered.

The purpose of this study was to examine one area of undocumented students' college access quandary-potentially prejudicial and discriminatory practices they have experienced during their college choice process. Specifically, this study sought to answer the following question: How, if at all, do undocumented students experience microaggressions during their college choice process? To help answer this question, we interviewed 15 undocumented immigrants who graduated from public high schools in New York City (NYC). This city was selected because of the large number of undocumented students residing in NYC and the limited research that has examined issues related to the college access of undocumented students in that major metropolis. We utilized the microaggressions framework created by Sue et al. (2007) and further developed by Sue (2010), and we identified nine types of microaggressions that participants faced in their college choice process. The article divides these nine categories into three types of microaggressions described by Sue et al. (2007): microassaults, microinsults, and microinvalidations.

We found that undocumented immigrants encountered cumulative episodes of microaggressions in their college choice process, sometimes delivered by well-intentioned institutional agents. ${ }^{2}$ In some cases, these 
experiences of microaggressions influenced decisions that undocumented students made in their college choice process. We end with implications for further research and practice in the area of microaggressions and undocumented students' college choice in an effort to further understand how to better meet this population's college access needs.

When we initially conceptualized this investigation, we set out to focus broadly on the role of stigma in undocumented students' college choice process. However, as we collected data and heard the personal experiences of the undocumented students who participated in this study, we realized the importance of reframing our work to illustrate instances in which undocumented youth experienced microaggressions in their college choice process. While undocumented students encounter overt forms of discrimination in their daily lives, we found that they experienced this in private conversations and one-on-one interactions with institutional agents during their college choice process. These experiences, coupled with others, could lead to these students feeling stigmatized. We begin this article with the literature that guided this research.

\section{EFFECT OF UNDOCUMENTED STATUS ON ADOLESCENTS AND EMERGING ADULTS}

Erikson (1968) defined the adolescent years as those between 12 and 18, and it is during this period that students develop a sense of identity. Arnett (2000) proposed a new developmental stage in between Erikson's adolescence and adulthood, one he named emerging adulthood. During this stage, development of individual character, self-reliance, independence, self-focus, and identity exploration occurs (Arnett \& Tanner, 2006; SuárezOrozco, Yoshikawa, Teranishi, \& Suárez-Orozco, 2011). This period is also characterized as a time of possibilities, optimism, and transformation, coupled with instability.

Undocumented students often face interrupted rites of passage and liminal legality (Menjívar, 2006, 2008) during adolescent and emerging adulthood years that may complicate their development (Gonzáles, 2011; Suárez-Orozco et al., 2011). Undocumented students have the legal safety and security of primary and secondary education, yet as they attempt to transition to higher education and/or work life, they realize that they do not have access to the same opportunities as their documented peers (Abrego, 2006; Menjívar, 2008). This recognition may prompt a decline in undocumented students' educational motivation (Abrego, 2006).

Undocumented immigrants' "perpetual legal limbo" (Menjívar, 2006, p. 1016) makes them potentially unable to freely travel (because of the federal government forbidding them from receiving a U.S. passport and 
some states outlawing them from obtaining a driver's license) and to receive federal or state (with the exception of five states) financial aid for higher education. As a result of these restricted life opportunities, undocumented students can get stuck in their developmental process and denied the ability to become adults (W. Pérez, 2012; Suárez-Orozco et al., 2011). Further, undocumented students' immigration "status [is] a constant reminder that they [are] different, vulnerable, and considered suspect" (Abrego, 2008, p. 723).

Another challenge that undocumented students face is choosing to whom they reveal their immigration status. The act of "coming out," typically associated with the lesbian/gay/bisexual/transgender/queer (LGBTQ) community, has recently been used to explain similar difficulties that undocumented youth encounter in sharing their immigration status with others (Enríquez, 2011). Beyond those strains, undocumented youth may experience the fear of deportation of themselves and/or their family, thoughts of uncertainty associated with their future, negative interactions with public officials (e.g., immigration officials, institutional agents), and the derogatory portrayal of immigrants (Del Razo, 2012; Morales, Herrera, \& Murry, 2011; Rivera, 2012; Suárez-Orozco et al., 2011).

\section{COLLEGE CHOICE}

The college choice process has been described as occurring in three phases: predisposition, search, and choice (Cabrera \& La Nasa, 2000; Hossler, Braxton, \& Coopersmith, 1989; Hossler \& Gallagher, 1987). Predisposition usually starts in the seventh grade and continues into the ninth grade. During this stage, students begin to think about educational plans upon completion of high school. These plans are shaped by the encouragement students receive, aspirations students hold, and information students acquire about higher education. The search stage typically happens during the tenth and eleventh grades, and it is when students explore and evaluate specific colleges and universities they may consider applying to. Students often tap into their networks (e.g., parents, siblings, peers, high school staff) for information and support during this stage (Hossler \& Gallagher, 1987). Finally, the choice stage often occurs during the eleventh and twelth grades, and it is when students select a postsecondary institution they plan to enroll in from among those considered. Typically, the most common factors that shape students' college choice are: (a) financial resources, (b) academic preparation and achievement, (c) support from significant others, and (d) knowledge and information about college and financial aid (Perna \& Kurban, 2013). 
Perna (2006) introduced a college choice conceptual model that focuses on the role of individual factors and contexts in shaping students' college choice. Specifically, this model illustrates how habitus (individual factors such as gender, race, and capital [social and cultural]); school and community context; higher education context; and social, economic, and policy context influence the college choice process of students. Although this conceptual model highlights the importance of individual characteristics, such as race/ethnicity and socioeconomic status, it neglects to emphasize the role that immigration status may have in shaping students' college choice. This model also highlights the importance of the availability of resources, types of resources, and structural supports and barriers that influence students' college choice. Low-income and minority students, the literature has found, often have less information and encounter difficulties with the college application process (Avery \& Kane, 2004; Kao \& Tienda, 1998). For example, minority students and their families are typically less informed about college admission and financial aid requirements (Kirst \& Venezia, 2004). Tierney (1980) demonstrated that students from low socioeconomic backgrounds had less access to sources of information as compared with higher level socioeconomic status students. To help mitigate this gap, school counselors are an important source of college application information for students of color (Kimura-Walsh, Yamamura, Griffin, \& Allen, 2009). However, counselors' high caseloads and extra responsibilities have resulted in less time being spent with students in addressing their needs, including the college choice process (Corwin, Venegas, Oliverez, \& Colyar, 2004; Perna, 2006).

It is important to note that these traditional college choice frameworks privilege and may resonate more with individuals who have documented status. In other words, such models may not fully describe the experiences that some undocumented students may encounter in their college choice process given the numerous barriers that typically define their college access, an area discussed next.

\section{UNDOCUMENTED STUDENTS' COLLEGE CHOICE}

The undocumented student college access literature identifies several factors that shape undocumented students' college choice: (a) limited availability of outreach efforts and information to assist undocumented students in their college choice process (Contreras, 2009; Enríquez, 2011; Gonzáles, 2010; Nienhusser, 2013; Olivas, 2009; Rincón, 2008), (b) discretionary application of complex residency requirements (Nienhusser, 2014; Olivas, 1988; Rincón, 2008), (c) high tuition rates in those states 
that do not offer in-state resident tuition to undocumented students who attend public postsecondary institutions (Dougherty et al., 2010; Flores, 2010), (d) little or no access to financial aid programs (Contreras, 2009; Gonzáles, 2010; Olivas, 2009; P. A. Pérez, 2010), and (e) strong feelings associated with fear of immigration status disclosure (Contreras, 2009; W. Pérez, 2012). Such barriers severely restrict undocumented students from enrolling in college, thus creating de jure oppression (Del Razo, 2012), which marginalizes these students and perpetuates feelings of second-class citizenship.

High school institutional agents (Stanton-Salazar, 1997, 2004, 2011) have a central function in shaping undocumented students' educational pathways. Institutional agents in high schools typically involve individuals such as counselors, principals, social workers, and teachers. Various studies (e.g., López, 2010; Nienhusser, 2013; W. Pérez, 2009, 2012; W. Pérez \& Cortés, 2011) have examined the role of these individuals in shaping undocumented students' college choice process. Some of these investigations have concluded that undocumented students have encountered largely positive (García \& Tierney, 2011; W. Pérez \& Cortés, 2011) or mixed experiences (López, 2010; W. Pérez, 2009) in their interactions with high school institutional agents.

Nienhusser (2013) identified five categories of activities that some NYC high schools have developed to address this population's college choice needs: one-on-one counseling for students and parents, presentations that specifically detail postsecondary education benefits for this population, outreach to colleges or community-based organizations for this population, scholarship opportunities, and courses embedded in the curriculum that provide information for undocumented students about their college choice. However, the number and intensity of these activities varied across high schools; those schools with elevated proportions of undocumented students had a higher number of activities and structured them in such a manner that these students would be more likely to be exposed to college choice information.

Although some scholarship has examined aspects related to undocumented students' college choice process, it has yet to examine the potential presence of microaggressions experienced by these students during their college choice process. It is important to examine this phenomenon because it may present yet another barrier that undocumented students must overcome in their attempt to access postsecondary education. 


\section{MICROAGGRESSIONS}

Sue (2010) defined microaggressions as "everyday verbal, nonverbal, and environmental slights, snubs, or insults, whether intentional or unintentional, that communicate hostile, derogatory, or negative messages to target persons based solely upon their marginalized group membership" (p. 3). Initially, Sue et al. (2007) focused on racial microaggressions. Later, Sue (2010) argued that microaggressions could be applied to other marginalized groups, such as people of color; women; lesbian, gay, bisexual, transsexual, and queer (LGBTQ) individuals; and people with disabilities. Microaggressions, some scholars argue, are modern-day discriminatory and prejudiced acts deemed more harmful than overt racism because they are cumulative, harder to identify, and thus more difficult to combat (Pierce, 1995; Solórzano, Ceja, \& Yosso, 2000; Sue, 2010). While the term microaggressions includes overt (traditional) acts of discrimination and the enactment of individuals' biases, it also comprises covert actions that individuals are unaware that they exhibit. These biases exist along a continuum of conscious awareness, in which individuals recognize these prejudices to those who are less aware of them (Sue, 2010). A further dimension of microaggressions is that they are often delivered by what Sue (2010) called "well-intentioned" individuals, people who are often unaware of how their actions have a harmful impact on marginalized individuals. Higher education scholars have used the microaggressions framework to study modern-day racism through the perspective of groups such as Black students (Beagan, 2001; McClelland \& Auster, 1990; Solórzano et al., 2000) and Latina/o students (Solórzano, 1998; Yosso, Smith, Ceja, \& Solórzano, 2009).

Microaggressions are manifested verbally (e.g., one-on-one interactions between individuals), nonverbally (e.g., behaviors that demonstrate aversion), or environmentally (e.g., conditions that create an unwelcoming climate; Sue, 2010). Sue noted three types of microaggressions: microassaults, microinsults, and microinvalidations. Microassaults are likened to incidents of overt racism because of perpetrators' intent to harm victims. They are characterized by their often intense nature, as in the use of racial epithets or not providing services to individuals because of their group identification. Microinsults are rude and insensitive remarks that demean victims' identity. Microinsults are often not overt and are remarks, comments, or behaviors that are said or done unconsciously and typically make the victim feel insignificant. Incidents of microinvalidation invalidate victims' experiences, thoughts, or knowledge. Microinvalidations are also delivered unintentionally and by perpetrators who are unconscious of their biases.

Wong, Derthick, David, Saw, and Okazaki (2014) noted how "microaggressions can also be perpetuated by macrolevel factors (e.g., laws, 
policies, etc.)" (p. 182). Yet, more research needs to be done to examine how these macrolevel factors (e.g., discriminatory policies) shape microaggressions and, more specifically, the interactions between perpetrators and victims. One dimension of this investigation examines the effects that discriminatory policies have in triggering microaggressions that are delivered by institutional agents to undocumented student during their college choice process.

In one of the few studies that have examined how undocumented youth have experienced microaggressions, Pérez Huber and Cueva (2012), identified episodes of racist nativist microaggressions experienced by undocumented Latinas in K-12 education. As a result of microaggression episodes, these Latina students also reported feeling academic self-doubt and inferiority, which impacted their college choice process; some did not apply to competitive universities that they were qualified to attend. Further, the internalization of these experiences had negative psychological and physiological effects on the students.

\section{NEW YORK STATE POLICY CONTEXT}

Nienhusser (2015) described New York's policy environment in providing undocumented students with postsecondary education benefits as contradictory because existent public policies both encourage and hinder greater higher education access. New York is one of 20 states (California, Colorado, Connecticut, Florida, Hawaii, Illinois, Kansas, Maryland, Minnesota, Nebraska, New Jersey, New Mexico, New York, Oklahoma, Oregon, Rhode Island, Texas, Utah, Washington, and Wisconsin) that have enacted laws that have redefined residency requirements for college tuition purposes and permitted certain undocumented immigrants to pay in-state resident tuition (ISRT) in public postsecondary institutions (IHELG, 2014; Nienhusser, 2015). In 2002, New York became the fourth state to enact an ISRT policy. New York has some of the least stringent requirements in the nation that make undocumented immigrants eligible for ISRT (Nienhusser, 2015). For instance, it requires them to have attended a high school in the state for only 2 years (some states require that students attended high school for 4 years). Furthermore, undocumented students who meet New York's ISRT requirements may begin their postsecondary studies at a four-year institution (in Maryland, for example, such students are required to begin their postsecondary education at a community college). However, New York has failed to extend state financial aid eligibility to undocumented students. In fact, a mere five states (California, Colorado, New Mexico, Texas, and Washington) grant state financial aid to this student population (IHELG, 2014; Nienhusser, 2015). 
Although a bill providing state financial aid to undocumented students has been proposed and voted on in Albany, it has failed to get the necessary number of votes in the Senate. As a result, New York continues to have higher education policies that discriminate against undocumented students and hinder their college access (Nienhusser, 2015).

\section{METHODOLOGY}

The following research question guided this study: How, if at all, do undocumented students experience microaggressions during their college choice process? This investigation followed a phenomenological research design. Phenomenological research describes how several individuals make meaning of their lived experiences (Creswell, 2013; Moustakas, 1994; Patton, 1990; Smith, Flowers, \& Larkin, 2009). A goal of phenomenological research is "uncovering an essential structure of a particular phenomenon that resonates with many individuals" (Jones, Torres, \& Arminio, 2014, p. 91). The use of a phenomenological research approach allows for the rich description of a phenomenon and for the phenomenon to speak for itself (Giorgi, 1985).

The selection of a phenomenological research approach for this study permitted us to present a detailed description of the phenomenon being studied-microaggressions that undocumented students have faced during their college choice process. The rich descriptions allowed us to include first-person accounts (Finlay, 2009) of undocumented students that include powerful quotes and messages that undocumented students shared with us as they recalled encountering microaggressions during their college choice process. Further, given the delicate nature of the topic of undocumented immigrants and episodes of microaggressions, phenomenological research is most appropriate because it allows a phenomenon to be examined in depth yet in a sensitive manner.

\section{INTERVIEW PARTICIPANTS}

Undocumented immigrants who were 18 years or older and completed high school in NYC were eligible to participate. Participants were recruited from researchers' existing networks, community-based organizations that assist undocumented students, and referrals from undocumented immigrants who were interviewed.

A total of 15 undocumented immigrants were interviewed between October 2012 and April 2013 (see Table 1). Our sample consisted of 10 females and 5 males. Twelve identified as Latina/o and 3 as Asian. Two participants never enrolled in postsecondary education. Of the 13 participants who enrolled in postsecondary education, 12 enrolled in a New 
York State public institution (one attended a public out-of-state university). Nine of the interviewees initially attended a four-year college, and four originally enrolled in a two-year institution.

The duration of each individual interview was approximately $50 \mathrm{~min}-$ utes. Interview data were collected using a semistructured interview format. The interview protocol contained three categories of questions: background (questions related to demographics and college enrollment information), college choice process, and effect of immigration status on college choice process.

\section{Table 1. Interview Participants}

\begin{tabular}{llcll}
\hline Gender & $\begin{array}{c}\text { Country of } \\
\text { birth }\end{array}$ & $\begin{array}{c}\text { Age at time } \\
\text { of interview }\end{array}$ & $\begin{array}{c}\text { Type of postsecond- } \\
\text { ary education institu- } \\
\text { tion first attended }\end{array}$ & Enrollment status \\
\hline Female & Colombia & 22 & Public (four-year) & Full-Time \\
Female & Ecuador & 21 & Public (four-year) & Full-Time \\
Female & Ecuador & 21 & Public (four-year) & Full-Time \\
Female & Hong Kong & 18 & Public (four-year) & Full-Time \\
Female & Mexico & 19 & Public (two-year) & Full-Time \\
Female & Mexico & 19 & Public (two-year) & Full-Time \\
Female & Mexico & 21 & Public (four-year) & Part-Time \\
Female & Mexico & 24 & Public (four-year) & Part-Time \\
Female & Peru & 21 & Public (two-year) & $\begin{array}{l}\text { Mixed (full-time then } \\
\text { part-time) }\end{array}$ \\
Female & Venezuela & 23 & Public (four-year) & $\begin{array}{l}\text { Mixed (full-time then } \\
\text { part-time) }\end{array}$ \\
Male & Guatemala & 28 & Did not enroll & Not Applicable \\
Male & Honduras & 19 & Public (two-year) & Part-Time \\
Male & Hong Kong & 25 & Public (four-year) & Part-Time \\
Male & Mexico & 21 & Did not enroll & Not Applicable \\
Male & South Korea & 33 & Public (four-year; & Full-Time \\
\hline
\end{tabular}

\section{DATA ANALYSIS}

The audio of each interview was transcribed and imported into NVivo. A coding scheme was developed using Sue's (2010) microaggressions framework. With this, the authors developed an initial list of codes (Miles \& Huberman, 1994). A representative subset of transcripts was analyzed, and adjustments were made to the coding scheme in response to key concepts 
raised by participants (Miles \& Huberman, 1994). Two researchers used this adjusted coding scheme to code all interview transcripts.

Creswell (2013) identified specific steps for how data from phenomenological studies should be analyzed, some of which include: (a) develop a list of significant statements, (b) take the significant statements and then group them into larger units of information, and (c) write a description of what the participants experienced (Creswell, 2013, p. 193). To accomplish this in this investigation, two researchers jointly analyzed the coded data of 5 randomly selected interviewees, which resulted in the identification of 24 themes. Following that, each of these researchers independently analyzed the data of 5 additional participants and placed significant statements into these 24 categories. Next, these researchers narrowed down these themes to 12 by combining categories or eliminating those that did not relate directly to microaggressions encountered in students' college choice process. A final round of analysis resulted in three themes being combined into other established themes, which resulted in a total of nine themes. The next section defines microassaults, microinsults, and microinvalidations in relation to undocumented students' college choice process. Further, it describes each of the nine themes, their frequency, and categorizes each theme by type of microaggression.

\section{FINDINGS AND DISCUSSION}

This investigation identified nine themes in the area of microaggressions that our sample faced in their college choice process: discriminatory financial aid policies, restricted college choice information, constrained life opportunities, denial of college opportunities, insensitive behaviors, insensitive college choice processes, narrowed college expectations, fear of coming out, and undocumented immigrant blindness. Every respondent who participated in our study encountered multiple episodes of these microaggressions in their college choice process. Some interviewees experienced as many as seven of the nine microaggressions we identified, and the fewest microaggressions encountered were four. ${ }^{3}$ We found that the interviewees faced cumulative and negative messages, behaviors, and environmental cues that pervaded their college choice process. Also, seemingly well-intentioned institutional agents often delivered many of the microaggressions encountered by students. These institutional agents, at times, communicated inaccurate college choice information and overtly discriminatory higher education policies to undocumented students. However, the manner in which these messages were delivered varied; many undocumented student respondents 
described episodes of microaggressions in which they encountered insensitive and unsympathetic institutional agents. Next, a description of each of the themes ensues, beginning with those we categorized as microassaults. After we describe the themes in each grouping, we provide a table that details a brief definition of each of the themes just discussed, examples of microaggressions, and messages that these microaggressions convey to undocumented students.

\section{MICROASSAULTS IN UNDOCUMENTED STUDENTS' COLLEGE CHOICE PROCESS}

We define microassaults as an explicit derogation characterized primarily by a strong verbal, nonverbal, or environmental attack during undocumented students' college choice process that results in marginalizing students through implementation of policies, avoidant behavior, or purposeful discriminatory actions. We categorized four of our themes as microassaults: discriminatory financial aid policies, restricted college choice information, constrained life opportunities, and denial of college opportunities.

\section{Discriminatory Financial Aid Policies}

Fourteen interviewees described how they experienced the microassault of discriminatory financial aid policies in their college choice process. This environmental microassault occurred when undocumented students encountered barriers, mostly related with discriminatory policies, in financing college attendance.

The absence of federal and state policies that make this population eligible for financial aid programs has created an environment in which undocumented students in most cases are not eligible for grants, loans, or work study funds to help finance their postsecondary attendance. Beyond public policies, institutional aid eligibility for undocumented students is not guaranteed because it is an institution-by-institution determination. In other words, postsecondary institutions have the authority to determine whether they will allocate institutional scholarship funds for undocumented students. One interviewee shared how she called several postsecondary institutions, only to be told that she would not be eligible for assistance and would have to fund her postsecondary education entirely on her own: "I would call a lot of private schools and public schools and they will tell me that I have to pay out of pocket and that I wouldn't qualify for financial aid. That was how I really, like how I became aware of what it meant to be undocumented." This de jure denial of resources creates an environment in which undocumented students 
regularly face microassaults in the area of limited financial assistance to pay for college attendance. Such incidents deliver messages to undocumented students such as, "The government continues to ignore me" or "I can't go to college."

The existence of such discriminatory policies, which are often implemented by institutional agents, makes these seemingly well-meaning stakeholders unintentional perpetrators by delivering microaggressions to undocumented students. The undocumented students we spoke with repeatedly heard statements from institutional agents similar to, "You can't submit a FAFSA," and "You're not going to get any financial aid."

As a result, some undocumented immigrants shared how their lack of financial opportunities left an emotional scar in their college choice process. A participant said, "My friends, you know they were applying to the right [colleges], they were getting financial aid, getting a full ride. I couldn't get any of that. So it did impact my personality, I guess it really made me a more negative person because I felt that it wasn't fair." Discriminatory financial aid policies to bar undocumented students from funding their college enrollment have produced an environment in which these students constantly encounter microaggressions during their college choice process.

\section{Restricted College Choice Information}

Thirteen respondents described instances in which they encountered a scarcity of college choice information. This was exhibited by respondents' descriptions of not receiving the information they needed to make informed college choice decisions. It was also evidenced by interviewees' accounts of the limited knowledge that institutional agents had regarding undocumented students' college choice process.

Interviewees described how they often felt that they did not have sufficient college choice information. In their interviews, they said they "[had] so many questions," "need [ed] to know more," and "[counselors] didn't really provide any help." As a result of the limited college choice information provided to students, they described feeling quite lost in the process and said, "I didn't know what to do," "How would you ask for information that you didn't even know what to ask for?" and "What should I do?"

Additionally, several interviewees mentioned how institutional agents were unaware of information specific to undocumented students' college choice process. As one interviewee described about her counselors, "They weren't really aware or knowledgeable about how [I should] go about [applying to college]." 
The lack of institutional agents' college choice knowledge was often attributed to respondents not feeling that these agents had taken the initiative to become informed of undocumented students' college choice needs. As a respondent shared with us, "[Counselors] didn't go and search for more information." Interestingly, several interviewees believed that institutional agents' knowledge was related to the number of undocumented students present in high schools; schools with reduced numbers of undocumented students were expected to have less informed institutional agents. As an interviewee shared, "[My counselor] cannot really help me that much since she's very limited due to the [small] number of undocumented students that are in our school."

Several respondents shared how it frustrated them to not receive college choice information during college information sessions that was specific to undocumented students. As one interviewee stated, "You're waiting [during presentations] for that undocumented part where [institutional agents are] like, 'Oh, for students who have this issue,' but they don't [provide that information]." Lack of information was not only harmful to the students but also added to further incidents of microaggressions, as evidenced by a participant who stated, "[My counselors] asked me what my Social Security number was, and I said that I don't have one. They were like 'How do you plan on applying?' And it was as if I had to educate them, instead of them helping me."

Yet another area of frustration undocumented students faced was misinformed institutional agents who provided wrong information to students. A respondent described her interactions with college officials this way:

The first time I called [the] records [office] they [said], "You will not be able to get in-state tuition." And so then I got frustrated. ... But then I called again and someone was like "Yeah, you can [get in-state tuition].”. . . [College officials] each have a different way that they, I guess, understand information they are given or they have the wrong information.

In short, there is a large knowledge gap in the area of undocumented students' college choice process. Both institutional agents and students often lacked adequate information to inform undocumented students' college choice process.

This microassault sends messages to undocumented students that institutional agents do not care about their college choice process. Students are left questioning why these staff members do not have such information and are unclear regarding what steps to take in thinking about, selecting, or enrolling in college, which makes this a frustrating experience. 


\section{Constrained Life Opportunities}

Around the same time undocumented students begin to witness the detriments that not having a Social Security number will have on college access, they realize how lack of status is also wrapped around other life opportunities. Thirteen respondents encountered the environmental microassault we labeled constrained life opportunities.

This microaggression is manifested when undocumented students encounter situations such as: (a) cannot apply for opportunities that will make their college application stronger (e.g., job, internship, volunteer opportunity), (b) consider if it is worth going to college because they may not be able to get a job after college, or (c) realize that college attendance will not change their immigration status.

One respondent reflected on how her inability to get a job because of her lack of a Social Security number impacted her thinking about postcollege opportunities. After not being able to get a job, she shared, "I got really, really frustrated. I'm like 'I can't even find a job ... how the hell am I going to find a job after I graduate with a degree and without a Social [Security number]?'” Another respondent also questioned attending college given the difficulty that would arise in trying to find a job afterward: "I would think it wasn't even worth it going to college then if [being denied a job] was going to be the case in every job that I applied to. So it made me ... wonder, it made me doubt about going to college." Thus, as undocumented students are undergoing their college choice process, they are forced to weigh how their lack of status intersects with limited life prospects.

\section{Denial of College Opportunities}

Ten respondents shared episodes of microaggressions that belonged to the theme, denial of college opportunities. Undocumented students encountered this theme when institutional agents told them that they should not apply to college or when they observed, typically through family members or peers, that their college choice process would be challenging. The current sociopolitical environment is hostile for undocumented immigrants and thus suitable for institutional agents to send messages that convey denial of educational opportunities to this population. Some institutional agents delivered messages with microaggressions to undocumented students such as, "You're undocumented, I'm sorry, but you can't go to college," "You need a Social Security number to apply to college," or "How do you plan on going to college?" These messages are incorrect and/or transmit to students that college is 
not an option for them. A participant, for example, shared the emotional difficulty he encountered when his counselor shared how enrolling in college would be "almost impossible":

I really wanted to cry because I had, I have a dream. I want a future, you know and so others telling you "No, that's not going to happen." Or "It's going to happen, but it's going to be hard." So in other words, if you want to go school, it's going to be almost impossible.

Further, the effects of undocumented students being exposed to stories of family members and friends who experienced microaggression during their college choice process impacted their own college choice experiences. One interviewee described how an uncle had been accepted to Columbia University but was unable to attend because of lack of status. Another respondent shared how seeing his older brother not attend college caused him to disengage from his academics to the point that he did not graduate from high school on time and decided not to attend college. Yet another interviewee shared how an undocumented friend in high school who was older than her encountered issues in his college choice process:

He was valedictorian of his class. ... And he was also undocumented. . . . And I realized that being undocumented was going to affect our lives. I remember him, doing an application for Princeton. . . . He could because he had the grades and he had [high test scores] and everything. But he lacked the Social Security [number], so it was a big disappointment.

Denial of college opportunities has a significant, and for some a scarring, effect on their college choice process. Indeed, the four microassaults just described were present in the college choice journeys of the majority of the interviewees. This is especially troublesome given that the microassault category contains the most intense types of microaggressions that individuals can face.

Table 2 includes a summary of these themes, examples of microaggressions within each theme, and messages that such episodes convey to undocumented youth. 


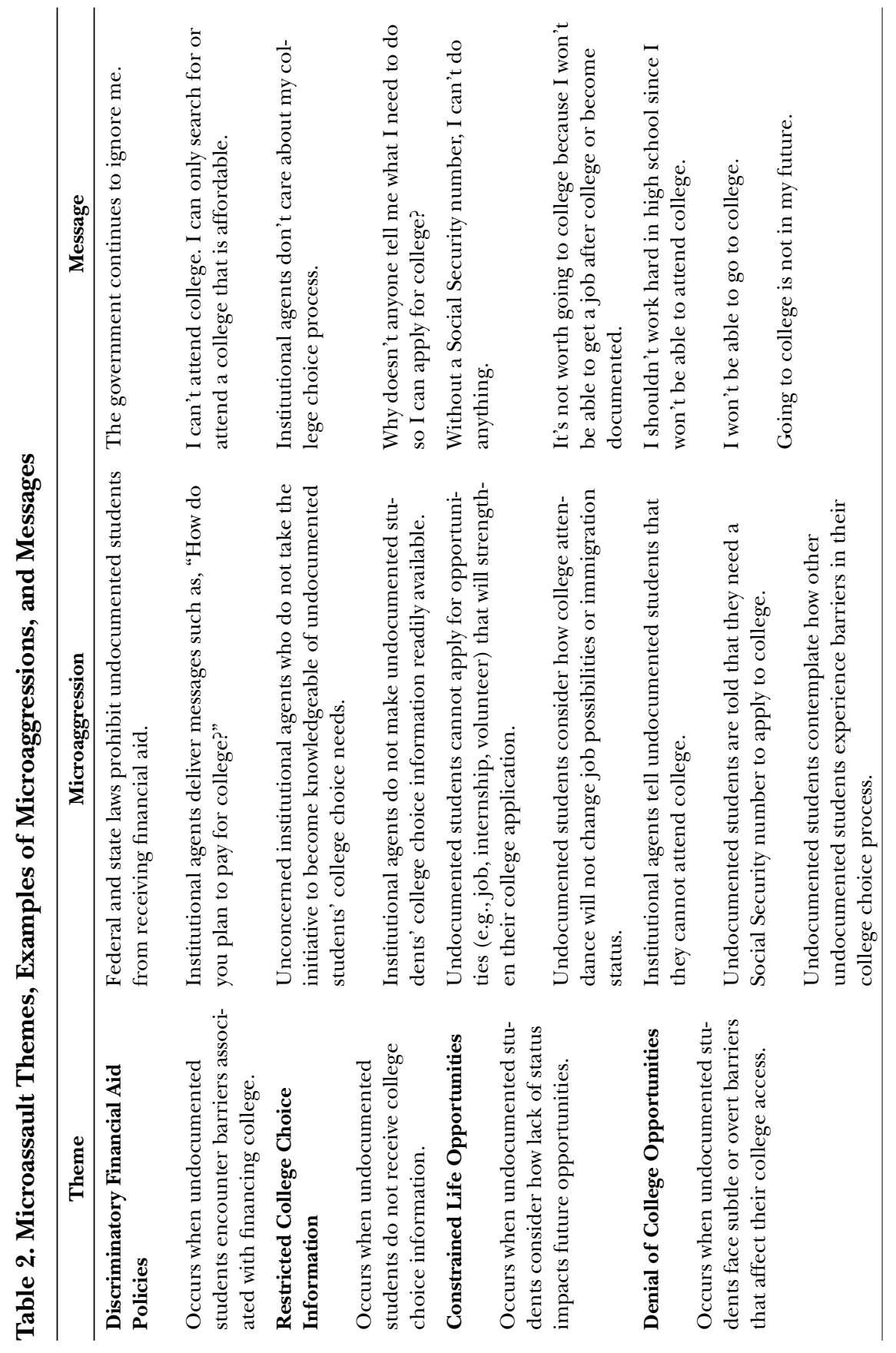




\section{MICROINSULTS IN THE UNDOCUMENTED STUDENTS' COLLEGE CHOICE PROCESS}

Microinsults are communications, typically delivered unconsciously, that convey rudeness and insensitivity and demean a person's immigration status. We found one theme in the microinsults category: insensitive behaviors.

\section{Insensitive Behaviors}

Insensitive behaviors, experienced by 7 interviewees, occurred when institutional agents treated undocumented students in an inconsiderate manner. This theme was manifested through institutional agents' insensitive treatment of undocumented students by: (a) failing to treat students' immigration status in a discreet manner; (b) engaging in inappropriate conversations with undocumented students, or (c) treating these students improperly upon finding out their status. Such episodes make undocumented students feel that their immigration status is a trigger for people to treat them differently or that they are a "foreigner."

Two interviewees, for example, shared how they encountered jokes from teachers about being undocumented. These jokes typically centered on how they arrived to the United States (e.g., "you must be a good swimmer," "did you run across the border?"). One respondent shared how he was exposed to insensitive jokes delivered by an instructor: "That teacher that I kept talking [to] did not know I was undocumented and would make jokes [about undocumented immigrants] without knowing that I was."

An interviewee reflected on whether college officials considered the manner in which they communicated information to undocumented students:

I don't know how people. . . . I want to ask them what goes through their head because sometimes it's like I don't think they really think or take a step back and say in their head, how do I put this gently or how do I say this. [A college official] was like, "Oh, we don't really have anything to offer. If you can't pay, then I'm sorry." I'm just like, "What do you mean?" From then, the conversation, it ended. It just didn't go anywhere.

These 7 respondents shared how the insensitive behaviors they encountered, mainly through well-intentioned institutional agents, were present in their college choice process.

Table 3 presents a summary of the insensitive behaviors theme, examples of microaggressions in this category, and messages that such episodes convey to undocumented students. 
Table 3. Microinsult Theme, Examples of Microaggressions, and Messages

\begin{tabular}{|c|c|c|}
\hline Theme & Microaggression & Message \\
\hline \multirow[t]{2}{*}{$\begin{array}{l}\text { Insensitive Behaviors } \\
\text { Occurs when institution- } \\
\text { al agents treat undocu- } \\
\text { mented students in an } \\
\text { inconsiderate manner. }\end{array}$} & $\begin{array}{l}\text { When institutional agents ask } \\
\text { inappropriate questions or } \\
\text { make insensitive comments } \\
\text { such as, "Oh, so you don't have } \\
\text { papers!" or "How did you get to } \\
\text { this country?" to an undocu- } \\
\text { mented student. }\end{array}$ & $\begin{array}{l}\text { Institutional agents are } \\
\text { insensitive of my immigra- } \\
\text { tion status. }\end{array}$ \\
\hline & $\begin{array}{l}\text { After undocumented students } \\
\text { reveal their status to institu- } \\
\text { tional agents, they are treated } \\
\text { poorly. }\end{array}$ & $\begin{array}{l}\text { My immigration status } \\
\text { makes others treat me } \\
\text { differently. }\end{array}$ \\
\hline
\end{tabular}

\section{MICROINVALIDATIONS IN UNDOCUMENTED STUDENTS' COLLEGE CHOICE PROCESS}

Microinvalidations, typically delivered unconsciously, are communications that exclude, negate, or nullify the thoughts, feelings, or experiential reality of undocumented immigrants. We found four themes in this category: insensitive college choice processes, narrowed college expectations, fear of coming out, and undocumented immigrant blindness.

\section{Insensitive College Choice Processes}

This microinvalidation, experienced by 10 interviewees, was evidenced when undocumented students encountered college choice processes that were not sensitive to their particular needs and/or required them to undergo additional actions.

One way that this was present was through the use of the Social Security number as an identifying tool or proxy for college choice processes. In an effort to address undocumented students' lack of a Social Security number, colleges have created alternative student identification numbers. However, this solution has created an unintended consequence because students who receive this number, some of whom are undocumented, are often easily identifiable and potentially could be treated differently. For example, at City University of New York (CUNY), this alternate number begins with the same three digits. Thus, some respondents shared how having this number made them vulnerable to their immigration status being discovered by staff, faculty, and/or peers.

Undocumented students are often required to go through additional steps in their college choice process. For example, in New York, like other 
states that have similar policies, undocumented students are required to complete an affidavit to be eligible for ISRT. In addition to creating an additional burden for undocumented students, these additional processes were not always clear. An interviewee shared how CUNY should make an effort to change the way that some of its institutions make the affidavit available to this population:

I would say their offices should be more organized. . . . Assume that if [students] are being charged with an out-of-state [tuition rate], and seeing that [their] application [for admission] has an actual in-state address, I think [they] should automatically include the affidavit in the whole process, rather than give [students] the run around. So I would include affidavit from the very beginning.

Instead of making the residency verification process easier for students, this process has produced anxiety and a sense of shame for undocumented students who must go though it. A respondent shared,

When you go enroll in school, you're first charged out-of-state tuition. I said, "Why am I being charged out-of-state?" And she said, "Because you are an international student." And I said "But I live here . . . I just don't have a social." And she's like, "Okay, bring proof that you've been living here for like five to seven years" or something like that.

\section{Narrowed College Expectations}

This microinvalidation, encountered by 10 interviewees, is a behavioral manifestation that occurs when institutional agents persuade undocumented students to apply to one kind of postsecondary institution or very limited types of institutions. These colleges tended to be the least expensive and have less selective postsecondary options. Participants often heard statements similar to "CUNY and SUNY are your only options." These microaggressions inferred that these students must be poor and could not afford other kinds of institutions. Some respondents we interviewed were actually economically able to afford colleges outside the state but were dissuaded by counselors to apply to private institutions. An interviewee recalled how "[counselors] helped more with public schools and not private schools. It kind of didn't really feel that great because I wanted to go to private schools." Although in states such as California, state institutions are considered prestigious, the New York postsecondary education culture often deems private institutions as more prestigious. A respondent who enrolled in a public four-year institution experienced a similar situation: 
[My counselor] was just like, "Well you know you're going to have problems getting into all of the [private] schools because how are you going to pay for it?" But that's it; I mean he wasn't like negative, like you can't go. ... He did tell me I should probably just go to CUNY because it is cheaper.

This theme reveals that institutional agents steered undocumented students to particular types of postsecondary institutions. Specifically, institutional agents direct undocumented students to more affordable college options, which are at times less prestigious, even though students might be academically qualified and able to attend more prestigious institutions.

\section{Fear of Coming Out}

Undocumented immigrants experience trepidation when they consider revealing their immigration status to others because they, and often their families, are at risk of deportation. The fear of coming out was described by 9 participants and occurs when undocumented students must consider and eventually often have to reveal their immigration status to institutional agents in order to receive college choice information that is specific to their situation. Another way this microaggression may present itself is when students evade institutional agents in an effort to avoid disclosing their immigration status. The messages that such incidents send to undocumented immigrants are that they are foreigners, they and their families are criminals, and they will always have to live with the fear that emanates from their status. An interviewee described her trepidation in relation to her status and how her family had taught her to avoid officials in an effort to conceal her status:

I was afraid of confronting any type of official, I was always taught to hide or run away from them, or to avoid them ... just because every official to us was always a threat or ... an ICE agent . . . so because of that fear that I might get deported if I speak about my status to anybody else, then that stopped me from actually stepping forward and acting.

Other respondents described the anxiety that emanated from considering sharing immigration status. As one interviewee said, "I guess you have to choose the right people whom to tell [about your status]. You couldn't just go about and carry a sign [that says], 'I am undocumented. I am not supposed to be here."'

Further, it is important to situate this fear of coming out that many undocumented youth experience during their college choice process 
alongside their developmental growth. As a participant said, undocumented youth often "don't have that confidence to go walk into [their] counselor's office and tell them about [their] situation."

\section{Undocumented Immigrant Blindness}

Finally, we found that 7 interviewees experienced what we labeled undocumented immigrant blindness, which is a microinvalidation that occurs when undocumented students are assumed to have been born in the United States or to have documentation. Our respondents encountered microaggressions similar to, "Wow! I had no idea you were undocumented." Such actions made undocumented students feel like "foreigners" even though in most scenarios they have been living in the United States most of their lives. In other cases, institutional agents and peers were not "conscious" of students' immigration status and therefore delivered verbal and nonverbal cues around the assumption that everyone was documented. An interviewee described how his counselor assumed that he was documented: "She never talked to me about a Social [Security number], because she expected me to have one." Such episodes may lead undocumented students to believe that they are the only undocumented person in their educational environment. A Mexican born male recalled:

After I had told [a friend of my undocumented status], first of all they didn't believe me, they were like, "No, you can't be. You, you just can't be." For whatever reason they didn't, just wouldn't want to accept it, and then they would ask questions of what it was like and like, what's going to happen you know, when you graduate, and some questions that I wouldn't even really bother thinking about.

Table 4 provides a summary of the four themes in the microinvalidation category along with examples of microaggressions in this category and the messages that such episodes can convey to undocumented students.

\section{LIMITATIONS}

As with all research, this study has some limitations. First, this investigation had a small sample, with 15 undocumented immigrants. Given the limited number of participants, it would be difficult to make the results of this study generalizable to describe the college choice experiences of all undocumented immigrants. Also, although the examination of one city added a focus and richness to this study, it is also a limitation. The NYC context is unique compared with other urban contexts, thus perhaps making the results specific only to NYC undocumented students. 


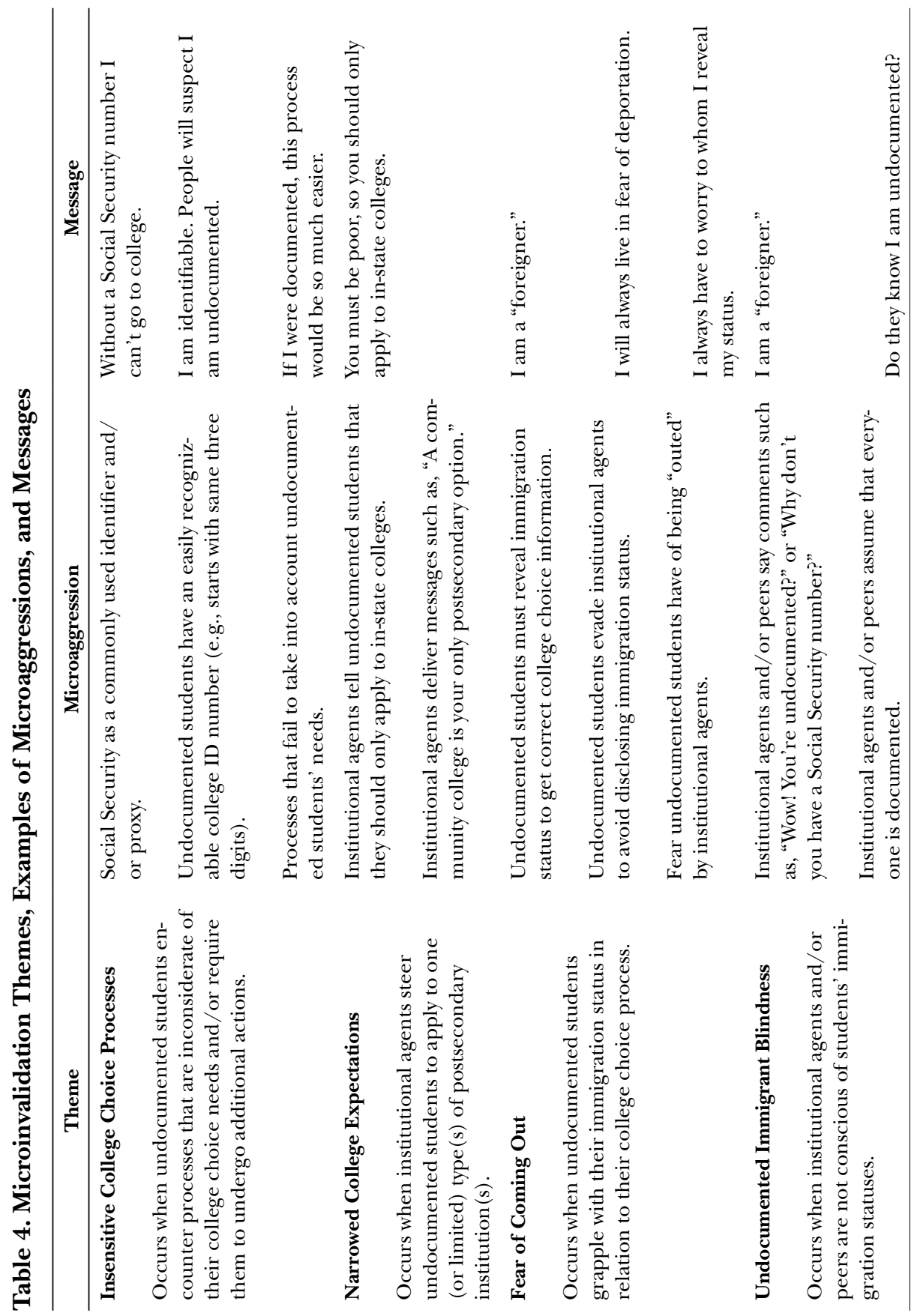


Last, as mentioned earlier, this study initially embarked on an examination of undocumented students' college choice through a stigma framework. We later decided to apply the microaggressions framework to help explain episodes of microaggressions that respondents reported experiencing during their college choice process. Thus, by not integrating the microaggressions framework from the beginning of the study, for example, we may have lost the opportunity to ask some questions of respondents that were more focused on microaggressions.

\section{IMPLICATIONS}

\section{PUBLIC POLICY}

As this study revealed, the postsecondary education journeys of undocumented students are severely limited because of the limited higher education benefits that are afforded to this population. Although this study took place in a state that affords ISRT to undocumented students, it is hypothesized that undocumented students who reside in states with more restrictive postsecondary education policies likely encounter more profound barriers, including microaggressions. Thus, the enactment of federal and state policies, such as the DREAM Act, state ISRT and financial aid laws, and local-level policies that offer postsecondary education benefits to undocumented students, is instrumental in providing postsecondary access to this population. Furthermore, the passage of such laws might help diminish the number of microaggressions that undocumented students face in their college choice process. As they currently stand, numerous public policies continue to discriminate against and segregate undocumented students. Further, these policies send signals to the broader society, including seemingly well-intentioned institutional agents, that it is acceptable to discriminate against this population.

\section{RESEARCH}

Although this investigation makes a significant contribution to the literature, more work needs to be done around the intersection of undocumented students' experiences with microaggressions and their college choice process. First, as mentioned earlier, the conventional college choice models do not fully address how, for example, discriminatory public policies and college access barriers faced by undocumented students make their college choice process different. Thus, additional studies that explore undocumented students' college choice process are needed in an effort to build a college choice model that best illustrates this population's unique college choice process. 
Second, the issue of intersectionality needs to be examined further in the literature. Intersectionality theorists (e.g., Collins, 1993; Crenshaw, 1989) and critical race theorists (e.g., Bell, 1987; Crenshaw, 1988; Delgado, 1995; Williams, 1995) have written about the importance of understanding multiple oppressions in individuals' lives, including the intersection of citizenship and race (Bell, 1987; Williams, 1995). The idea of multiple oppressions is especially important in understanding the lives of undocumented students given that an overwhelming majority of undocumented students belong to a racial/ethnic minoritized group, come from low-income families, and/or face the indignities of belonging to an oppressed gender or sexual identity group. Thus, applying a critical race lens and, more generally, applying an intersectional analysis to fully understand the microaggressions that arise from multiple oppressions will provide a richer perspective of what undocumented students face as they encounter their college choice process.

Third, research is needed to further understand the psychological toll that microaggressions encountered during the college choice process have on the development of undocumented youth during the adolescent and emerging adulthood stages. It would be important to describe and understand undocumented students' reactions and responses to such potentially damaging incidents. Also, while all respondents shared incidents of microaggressions in their college choice process, some also shared instances in which institutional agents were supportive. Thus, it would be imperative to examine the role that institutional agents have in mitigating microaggressions and supporting these students in their college choice process.

Last, our study demonstrated that federal and state policies make it legal and acceptable for institutional agents, even those who are well intentioned, to create environments that discriminate and perpetuate prejudicial laws against undocumented immigrants. Therefore, we must further understand how institutional agents deal with this potential conflict in their daily practice and ways in which they can combat this impelled role of perpetrator. Within the microaggressions literature, as noted by Wong et al. (2014), more research is needed to further understand the role that macrolevel factors have in shaping microaggressive encounters.

\section{PRACTICE}

Our research revealed that institutional agents are integrally involved in creating an environment that is supportive of or detrimental to undocumented students' college choice process. First, given the unique process that is undocumented students' college choice, it is imperative 
that institutional agents (at both high schools and higher education institutions) be equipped with knowledge about public and institutional policies, institutional procedures, and resources that involve this population's college access. Similarly, given the challenges that undocumented students undergo in this process, it is important that institutional agents receive sensitivity training to be more conscious of how actions (verbal and nonverbal) and educational environments may have a negative impact on these students' college access. Finally, it is necessary for institutional agents to create processes that are more sensitive to undocumented students' college choice needs (e.g., not using a Social Security number as a identifier and/or proxy). Thus, institutional agents should reexamine all processes related to students' college choice and examine ways that they can make these processes easier to navigate for undocumented students.

\section{CONCLUSION}

Although the undocumented student college access literature demonstrates that there are very real barriers that contribute to only $25 \%$ of this population enrolling in college, what the literature rarely demonstrates are the subtle forms of discrimination and prejudice experienced by this population during their college choice process. These forms of discrimination and prejudice, microaggressions, can be avoided if brought to light and shared with potential, unintentional perpetrators. Because these microaggressions range from severe, such as microassaults, to less detectable, such as microinsults and microinvalidations, they can be missed or even dismissed by undocumented students. But our work demonstrates that undocumented students face very specific types of microaggressions in their college choice process. Our nine themes demonstrate that undocumented students experience multiple forms of prejudice, some of which emanate from federal, state, and institutional policies that have created environments that target this group's college access. Thus, research must take a step forward in understanding how these barriers affect undocumented students and promote a hostile environment. Our practice must be consistent with our desire to create college choice processes that take into account undocumented students' needs. Until such processes are adequately addressed, we will continue to contribute to the high percentage of undocumented students who are unable to enroll in postsecondary education. 


\section{NOTES}

1. On June 15, 2012, President Obama announced his DACA plan, which grants some undocumented immigrants prosecutorial discretion from deportation, ability to receive a Social Security number, and authorization to work. DACA, however, does not guarantee postsecondary education benefits to this population, which makes their college choice process different when compared with documented peers.

2. For this study, institutional agents (Stanton-Salazar, 1997, 2004, 2011) refers to high school staff (e.g., counselors and teachers) and college officials (e.g., admissions, financial aid, and registrar officials).

3 . The following is a breakdown of the number of microaggression themes that we identified were experienced by respondents: four microaggression themes were faced by 2 interviewees; five themes were encountered by 3 respondents; six themes were experienced by 8 individuals; and seven microaggression themes were experienced by 2 interviewees.

\section{ACKNOWLEDGMENTS}

The authors would like to thank the following individuals for their feedback on earlier versions of this manuscript: Susana Muñoz, Ebelia Hernández, Derald Wing Sue, Jane Sinagub, and Teachers College Record reviewers and editors. We would also like to acknowledge Hispanic Association for Colleges and Universities (HACU) for funding this research. 


\section{REFERENCES}

Abrego, L. J. (2006). "I can't go to college because I don't have papers": Incorporation patterns of Latino undocumented youth. Latino Studies, 4(3), 212-231.

Abrego, L. J. (2008). Legitimacy, social identity, and the mobilization of law: The effects of Assembly Bill 540 on undocumented students in California. Law E Social Inquiry, 33(3), 709-734.

Arnett, J. J. (2000). Emerging adulthood: A theory of development from the late teens through the twenties. American Psychologist, 55(5), 469-480.

Arnett, J. J., \& Tanner, J. L. (Eds.). (2006). Emerging adults in America: Coming of age in the $21^{\text {st }}$ century. Washington, DC: American Psychological Association.

Avery, C., \& Kane, T. J. (2004). Student perceptions of college opportunities. The Boston COACH program. In C. M. Hoxby (Ed.), College choices: The economics of where to go, when to go, and how to pay for it (pp. 355-394). Chicago, IL: University of Chicago.

Beagan, B. (2001). Micro inequities and everyday inequalities: "Race," gender, sexuality and class in medical school. Canadian Journal of Sociology, 26(4), 583-610. doi: $10.2307 / 3341493$

Bell, D. (1987). And we are not saved: The elusive quest for racial justice. New York, NY: Basic Books.

Cabrera, A. F., \& La Nasa, S. M. (2000). Understanding the college-choice process. New Directions for Institutional Research, 27(3), 5-22. http://dx.doi.org/10.1002/ir.10701

Collins, P. H. (1993). Toward a new vision: Race, class, and gender as categories of analysis and connection. Race, Sex, and Class, 1(1), 25-45.

Congressional Budget Office. (2007). The impact of unauthorized immigrants on the budgets of state and local governments. Washington, DC: Author. Retrieved from http://www.cbo.gov/ sites/default/files/cbofiles/ftpdocs/87xx/doc8711/12-6-immigration.pdf

Contreras, F. (2009). Sin papeles y rompiendo barreras: Latino students and the challenges of persisting in college. Harvard Educational Review, 79(4), 610-631.

Corwin, Z. B., Venegas, K. M., Oliverez, P. M., \& Colyar, J. E. (2004). School counsel: How appropriate guidance affects educational equity. Urban Education, 39(4), 442-457.

Crenshaw, K. W. (1988). Race, reform, and retrenchment: Transformation and legitimation in antidiscrimination law. Harvard Law Review, 101(7), 1331-1387.

Crenshaw, K. W. (1989). Demarginalizing the intersection of race and sex: A Black feminist critique of antidiscrimination doctrine, feminist theory and antiracist politics. University of Chicago Legal Forum, 140, 139-168.

Creswell, J. W. (2013). Qualitative inquiry and research design: Choosing among five approaches (3rd ed.). Thousand Oaks, CA: Sage.

Delgado, R. (Ed.). (1995). Critical race theory: The cutting edge. Philadelphia, PA: Temple University Press.

Del Razo, J. L. (2012). Echándole ganas: Undocumented, Latino students fighting for collegiate survival in their United States homeland (Doctoral dissertation). Retrieved from ProQuest. (AAT No. 3526883)

Dougherty, K. J., Nienhusser, H. K., \& Vega, B. E. (2010). Undocumented immigrants and state higher education policy: The politics of in-state tuition eligibility in Texas and Arizona. Review of Higher Education, 34(1), 123-173.

Enríquez, L. E. (2011). "Because we feel the pressure and we also feel the support": Examining the educational success of undocumented immigrant Latina/o students. Harvard Educational Review, 81(3), 476-499.

Erikson, E. H. (1968). Identity: Youth and crisis. New York, NY: Norton. 
Federation for American Immigration Reform. (2005). New York: Illegal aliens. Washington, DC. Retrieved from http://www.fairus.org/site/PageServer ?pagename= research_researchb009\&s_oo=ctx1uVr4-MQymGfHk5Insg

Finlay, L. (2009). Debating phenomenological research methods. Phenomenology Eo Practice, $3(1), 6-25$.

Flores, S. M. (2010). State Dream Acts: The effect of in-state resident tuition policies and undocumented Latino students. Review of Higher Education, 33(2), 239-283.

García, L., \& Tierney, W. (2011). Undocumented immigrants in higher education: A preliminary analysis. Teachers College Record 113(12). Retrieved from http://www.tcrecord.org

Giorgi, A. (1985). Phenomenology and psychological research. Pittsburgh, PA: Duquesne University Press.

Gonzáles, R. G. (2010). On the wrong side of the tracks: Understanding the effects of school structure and social capital in the educational pursuits of undocumented immigrant students. Peabody Journal of Education, 85(4), 469-485. doi:10.1080/016195 6X.2010.518039

Gonzáles, R. G. (2011). Learning to be illegal: Undocumented youth and shifting legal contexts in the transition to adulthood. American Sociological Review, 76(4), 602-619. doi:10.1177/0003122411411901

Hossler, D., Braxton, J., \& Coopersmith, G. (1989). Understanding student college choice. In J. C. Smart (Ed.), Higher education: Handbook of theory and research (Vol. 5, pp. 231-288). New York, NY: Agathon.

Hossler, D., \& Gallagher, L. (1987). Studying college choice: A three-phase model and the implication for policy makers. College and University, 62(3), 207-221.

Institute for Higher Education Law and Governance. (2014). Table one: State laws allowing undocumented college students to establish residency, 2014. Retrieved from http:// www.law.uh.edu/ihelg/documents/Statute-TableOne.html

Jones, S. R., Torres, V., \& Arminio, J. (2014). Negotiating the complexities of qualitative research in higher education: Fundamental elements and issues. Boca Raton, FL: CRC.

Kao, G., \& Tienda, M. (1998). Educational aspirations of minority youth. American Journal of Education, 106(3), 349-384.

Kimura-Walsh, E., Yamamura, E. K., Griffin, K. A., \& Allen, W. R. (2009). Achieving the college dream? Examining disparities in access to college information among high achieving and non-high achieving Latina students. Journal of Hispanic Higher Education. $8(3), 298-315$.

Kirst, M., \& Venezia, A. (2004). From high school to college: Improving opportunities for success in postsecondary education. San Francisco, CA: Jossey-Bass.

López, J. (2010). Undocumented students and the policies of wasted potential. El Paso, TX: LFB Scholarly Publishing.

McClelland, K., \& Auster, C. (1990). Public platitudes and hidden treasures: Racial climates at predominantly White liberal arts colleges. Journal of Higher Education, 61(6), 601-642.

Menjívar, C. (2006). Liminal legality: Salvadoran and Guatemalan immigrants' lives in the United States. American Journal of Sociology, 111(4), 999-1037.

Menjívar, C. (2008). Educational hopes, documented dreams: Guatemalan and Salvadoran immigrants' legality and educational prospects. The ANNALS of the American Academy of Political and Social Science, 620(1), 177-193.

Miles, M. B., \& Huberman, A. M. (1994). Qualitative data analysis: An expanded sourcebook (2nd ed.). Thousand Oaks, CA: Sage.

Morales, A., Herrera, S., \& Murry, K. (2011). Navigating the waves of social and political capriciousness: Inspiring perspectives from Dream-eligible immigrant students. Journal of Hispanic Higher Education, 10(3), 266-283. doi:10.1177/1538192708330232 
Moustakas, C. (1994). Phenomenological research methods. Thousand Oaks, CA: Sage.

Nienhusser, H. K. (2013). Role of high schools in undocumented students' college choice. Education Policy Analysis Archives, 21(85), 1-32.

Nienhusser, H. K. (2014). Role of community colleges in the implementation of postsecondary education enrollment policies for undocumented students. Community College Review. 42(1), 3-22.

Nienhusser, H. K. (2015). Undocumented immigrants and higher education policy: The policymaking environment of New York State. Review of Higher Education, 38(2), 271-303.

Olivas, M. A. (1988). Administering intentions: Law, theory, and practice of postsecondary residency requirements. Journal of Higher Education, 59(3), 263-290. doi:10.2307/1981679

Olivas, M. A. (2009). Undocumented college students, taxation, and financial aid: A technical note. Review of Higher Education, 32(3), 407-416. doi:10.1353/rhe.0.0068

Olivas, M. A. (2012, June 18). Obama's new immigration policy: Disappointment is in the details [Commentary]. Chronicle of Higher Education. Retrieved from http://chronicle. com/article/article-content/132377

Passel, J., \& Cohn, D. (2009). A portrait of unauthorized immigrants in the United States. Retrieved from Pew Hispanic Center: http://www.pewhispanic.org/files/reports/107.pdf

Passel, J., \& Cohn, D. (2010). U.S. unauthorized immigration flows are down sharply since middecade. Retrieved from Pew Hispanic Center: http://www.pewhispanic.org/files/ reports/126.pdf

Patton, M. Q. (1990). Qualitative evaluation and research methods (2nd ed.). Thousand Oaks, CA: Sage.

Pérez, P. A. (2010). College choice process of Latino undocumented students: Implications for recruitment and retention. Journal of College Admission, 206, 21-25.

Pérez, W. (2009). We are Americans: Undocumented students pursuing the American dream. Sterling, VA: Stylus.

Pérez, W. (2012). Americans by heart: Undocumented Latino students and the promise of higher education. New York, NY: Teachers College Press.

Pérez, W., \& Cortés, R. D. (2011). Undocumented Latino college students: Their socioemotional and academic experiences. El Paso, TX: LFB Scholarly Publishing.

Pérez Huber, L., \& Cueva, B. M. (2012). Chicana/Latina testimonios on effects and responses to microaggressions. Equity and Excellence in Education, 45(3), 392-410.

Perna, L. W. (2006). Studying college access and choice: A proposed conceptual model. Higher Education: Handbook of Theory and Research, 21, 99-157. doi:10.1007/1-4020-4512-3_3

Perna, L. W., \& Kurban, E. R. (2013). Improving college access and choice. In L. W. Perna \& A. P. Jones (Eds.), The state of college access and completion: Improving college success for students from underrepresented groups (pp. 10-33). New York, NY: Routledge.

Perry, A. (2004). Philosophical arguments of membership: The case of undocumented immigrants and financial aid for postsecondary education (Unpublished doctoral dissertation). College Park: University of Maryland.

Pierce, C. (1995). Stress analogs of racism and sexism: Terrorism, torture, and disaster. In C. Willie, P. Rieker, B. Kramer, \& B. Brown (Eds.), Mental health, racism, and sexism (pp. 277-293). Pittsburgh, PA: University of Pittsburgh.

Rincón, A. (2008). Undocumented immigrants and higher education: Si se puede. El Paso, TX: LFB Scholarly Publishing.

Rivera, D. P. (2012). Microaggressions and health outcomes for Latina/o Americans: Understanding the influences of external characteristics and psychological resources (Doctoral dissertation). Retrieved from ProQuest. (AAT No. 3525646)

Smith, J. A., Flowers, P., \& Larkin, M. (2009). Interpretative phenomenological analysis: Theory, method, and research. Thousand Oaks, CA: Sage. 
Solórzano, D. G. (1998). Critical race theory, race and gender microaggressions, and the experience of Chicana and Chicano scholars. International Journal of Qualitative Studies in Education, 11(1), 121-136. doi:10.1080/095183998236926

Solórzano, D. G., Ceja, M., \& Yosso, T. (2000). Critical race theory, racial microaggressions, and campus racial climate: The experiences of African American college students. Journal of Negro Education, 69(1/2), 60-73.

Stanton-Salazar, R. D. (1997). A social capital framework for understanding the socialization of racial minority children and youths. Harvard Educational Review, 67(1), 1-40. doi: $10.1177 / 0044118 X 10382877$

Stanton-Salazar, R. D. (2004). Social capital among working-class minority students. In M. Gibson, P. Gándara, \& J. Koyama (Eds.), School connections: U.S. Mexican youth, peers, and school achievement (pp. 18-37). New York, NY: Teachers College Press.

Stanton-Salazar, R. D. (2011). A social capital framework for the study of institutional agents and their role in the empowerment of low-status youth. Youth E्F Society, 43(3), 1066-1109.

Suárez-Orozco, C., Yoshikawa, H., Teranishi, R. T., \& Suárez-Orozco, M. M. (2011). Growing up in the shadows: The developmental implications of unauthorized status. Harvard Educational Review, 81(3), 438-472.

Sue, D. W. (2010). Microaggressions in everyday life: Race, gender, and sexual orientation. Hoboken, NJ: John Wiley \& Sons.

Sue, D. W., Capodilupo, C. M., Torino, G. C., Bucceri, J. M., Holder, A., Nadal, K. L., \& Esquilin, M. (2007). Racial microaggressions in everyday life: Implications for clinical practice. American Psychologist, 62(4), 271-286. doi:10.1037/0003-066X.62.4.271

Tierney, M. S. (1980). The impact of financial aid on student demand for public/private higher education. Journal of Higher Education, 51(5), 527-545.

Williams, P. (1995). Alchemical notes: Reconstructing ideals from deconstructed rights. In R. Delgado (Ed.), Critical race theory: The cutting edge (pp. 84-94). Philadelphia, PA: Temple University Press.

Wong, G., Derthick, A. O., David, E. J. R., Saw, A., \& Okazaki, S. (2014). The what, the why, and the how: A review of racial microaggressions research in psychology. Race and Social Problems, 6(2), 181-200.

Yosso, T. J., Smith, W. A., Ceja, M., \& Solórzano, D. G. (2009). Critical race theory, racial microaggressions, and campus racial climate for Latina/o undergraduates. Harvard Educational Review, 79(4), 659-691. 
H. KENNY NIENHUSSER is an assistant professor of Educational Leadership at the University of Hartford.

BLANCA E. VEGA is the daughter of Ecuadorian immigrants. She is currently a doctoral candidate in the Higher and Postsecondary Education program at Teachers College, Columbia University. Blanca's research, teaching, and administrative work centers on access to, persistence in, and completion of postsecondary education for underserved populations. Blanca has done research and has publications in the following areas: campus racial culture; critical race theory; undocumented immigrants in higher education; and performance funding in higher education.

MARIELLA CRISTINA SAAVEDRA CARQUIN works as a psychotherapist at Psychotherapy and Counseling Center in Queens, New York, and as a transfer advisor at Kingsborough Community College. She earned her Ed.M. and M.A. in psychological counseling at Teachers College, Columbia University. Her research interests include identity development, college access, and the psychological impact of immigration status on undocumented immigrants. 